J. Perinat. Med. 2 (1974) 122

\section{A combined clinical-biochemical scoring of the newborn Results of the past four years}

\author{
Herbert Boenisch, Erich Saling \\ Unit of Perinatal Medicine - The Free University of Berlin \\ Department of Obstetrics and Gynecology, Berlin - Neukölln
}

Received January 10, 1974. Accepted March 15, 1974.
In 1953 Virginia Apgar was the first to introduce clinical scoring of the newborn [1]. The scoring system she introduced is now being used in almost every country. As with other similar clinical classification methods her system has the disadvantage of providing no exact measurable value and thus is prone to subjective influences.

The co-author of this article introduced fetal blood analysis [2]; he recommended as early as 1965 that - supplementary to this biochemical assessment of the fetus - in addition to the clinical scoring, the pH-value in the umbilical artery blood be measured as a further parameter for the condition of the newborn [3].

To obtain a better over-all view of the judgement of the newborn we split together with WULF [4] the clinical and the acidity score into groups (Fig. 2).

Since 1960 this acidity scoring has been employed at our clinic in all cases at risk in which fetal blood analysis (FBA) has been carried out; thus we have today a large number of newborn which have been observed in this manner (Tab. I). The percentage of fetuses observed by FBA in 1961 was only $5.1 \%$, rising to about $50 \%$ in the last years (Tab. I). The reason for this increase was that the indication for FBA was broadened from year to year by increasingly intensive methods of diagnosis, cardiotocography in particular.

At first we evaluated this large group of cases, to determine how many of the infants, supervised by using FBA, were born in an unsatisfactory

\section{Curriculum vitae}

HERBERT BOENISCH was born in 1945 in Ranis/Thüringen and attended school in Berlin from 1953 to 1964. Afterwards be studied at the Free University of Berlin and passed state-board-examinations in medicine at the beginning of 1970. He obtained bis degree as $M$. D. in 1972. From 1971 to 1972 be had been a member of the Unit Perinatal Medicine of the Free University of Berlin. Since the end of 1972 be is working at the cbildren's clinic of Berlin-Neukölln.

condition. The percentage of such cases fell rapidly. However, since the number of infants supervised by FBA rose constantly, we did not feel justified in attributing the above decrease to improved clinical techniques alone. For this reason the complete clinical data had to be examined.

\section{Data and methods}

Our aim was to test whether the increasingly better diagnostic and therapeutic advances of the past few years led to a decrease in morbidity - i. e. fewer cases of acidosis and clinical depression.

Since July 1, 1970 for every child born in our department a clinical score (Fig. 1) was estimated [3] and the $\mathrm{pH}$-value in the umbilical artery blood was registered. In the second half of 1970 the percentage of such a combined clinical- 


\begin{tabular}{lcccc}
\hline \multicolumn{1}{c}{ Score } & 3 & 2 & 1 & 0 \\
\hline Cord & tight & - & moderately filled & flaccid \\
Trunk-color & pink & blue & pale blue & pale \\
Muscle tone, movements & strong, vigorous & good & reduced & absent \\
Respiration, first 11/2 min & with frequent cries & $\begin{array}{c}\text { undisturbed } \\
\text { (rare or no cries) }\end{array}$ & disturbed, gasping & absent \\
\hline
\end{tabular}

Fig. 1. Scoring system modified by us in 1965 [3]. Score signs have to be judged immediately after delivery, respiration within $1 \frac{1}{2}$ minutes. A newborn baby in optimal condition scores 12 points.

\section{Clinical score}

\begin{tabular}{llcl}
\hline APGAR & $\begin{array}{c}\text { our } \\
\text { system }\end{array}$ & clinical condition & symbol \\
\hline $9-10$ & $9-12$ & optimal vigorous & C V \\
$7-8$ & $7-8$ & still vigorous & C IV \\
$5-6$ & $5-6$ & slightly depressed & C III \\
$3-4$ & $3-4$ & moderately depressed & C II \\
$0-2$ & $0-2$ & severely depressed & C I \\
\hline
\end{tabular}

Acidity score

\begin{tabular}{|c|c|c|}
\hline $\begin{array}{l}\text { umbilical } \\
\text { artery } \\
\text { pH act. }\end{array}$ & state of acidity & symbol \\
\hline $\begin{array}{c}\geqq 7.30 \\
7.20-7.29\end{array}$ & $\begin{array}{l}\text { normal acidity } \\
\text { slightly to moderately } \\
\text { increased acidity }\end{array}$ & $\begin{array}{l}\text { A V } \\
\text { A IV }\end{array}$ \\
\hline $7.10-7.19$ & slight to moderate acidosis & A III \\
\hline $7.00-7.09$ & advanced acidosis & A II \\
\hline$<7.00$ & severe acidosis & A I \\
\hline
\end{tabular}

Fig. 2. Grouping of scoring-systems relating the clinical condition and the acidity state of newborn [4].

biochemical scoring reached $83.8 \%$, rising in later years to $97-99 \%$ of all living newborn.

The blood sample is taken immediately after delivery (before the first breath) from the umbilical artery. The $\mathrm{pH}$-measurement is performed a few minutes thereafter in order to ensure that no change takes place in the composition of the blood sample and that buffer-treatment of the newborn can be introduced quickly.

All our data are based upon the actual $\mathrm{pH}$-value.

Statistical calculations have been performed to test whether there were significant differences
Tab. I. Number of labors monitored by fetal blood analysis. In 1960 we had only a few cases.

\begin{tabular}{cccc}
\hline Ycar & $\begin{array}{c}\text { Total No. of } \\
\text { deliveries }\end{array}$ & $\begin{array}{c}\text { No. } \\
\text { monitored } \\
\text { by FBA }\end{array}$ & $\begin{array}{c}\text { Incidence } \\
\text { of FBA }\end{array}$ \\
\hline 1961 & 2.347 & 120 & $5.1 \%$ \\
1962 & 2.539 & 289 & $11.4 \%$ \\
1963 & 2.776 & 287 & $10.3 \%$ \\
1964 & 2.726 & 465 & $17.1 \%$ \\
1965 & 2.680 & 568 & $21.2 \%$ \\
1966 & 2.709 & 703 & $26.0 \%$ \\
1967 & 2.586 & 743 & $28.7 \%$ \\
1968 & 2.499 & 626 & $24.9 \%$ \\
1969 & 2.514 & 776 & $30.9 \%$ \\
1970 & 2.501 & 1.043 & $42.2 \%$ \\
1971 & 2.391 & 1.225 & $51.7 \%$ \\
1972 & 1.821 & 907 & $50.3 \%$ \\
1973 & 1.683 & 796 & $47.4 \%$ \\
\hline
\end{tabular}

between 1970 and 1973; we set up four fould tables and applied the "chi-square-test" to them.

\section{Results and discussion}

The postnatal condition of the infants born in our clinic in the last four years as well as the particular method of delivery are shown in the following figures and tables.

We note throughout an almost continuous decrease in cases of neonatal acidosis $(\mathrm{pH}<$ 7.20) and clinical depression (score $<7$ ) (Fig. 3, Tab. II). This decrease is statistically highly significant (Tab. IV).

Cases of acidosis occurred in the last year in only $9.2 \%$, clinical depression in $4.5 \% ; 1.5 \%$ of the newborn suffered from acidosis as well as clinical depression. 
The number of vigorous infants $(\mathrm{pH} \geqq 7.20$ and clinical score $\geqq 7$ ) rose correspondingly and significantly in the same period (Fig. 4, Tabs. II and IV). In $197387.7 \%$ of the newborn were vigorous.

It is encouraging to note that the percentage of Cesarean sections has remained more or less the same (Fig. 7).

Also an examination of the data concerning the different methods of delivery shows on the whole a decrease in cases of acidosis and clinical depression (Figs. $5 \mathrm{a}-\mathrm{d}$, Tabs. III and IV). Fluc-
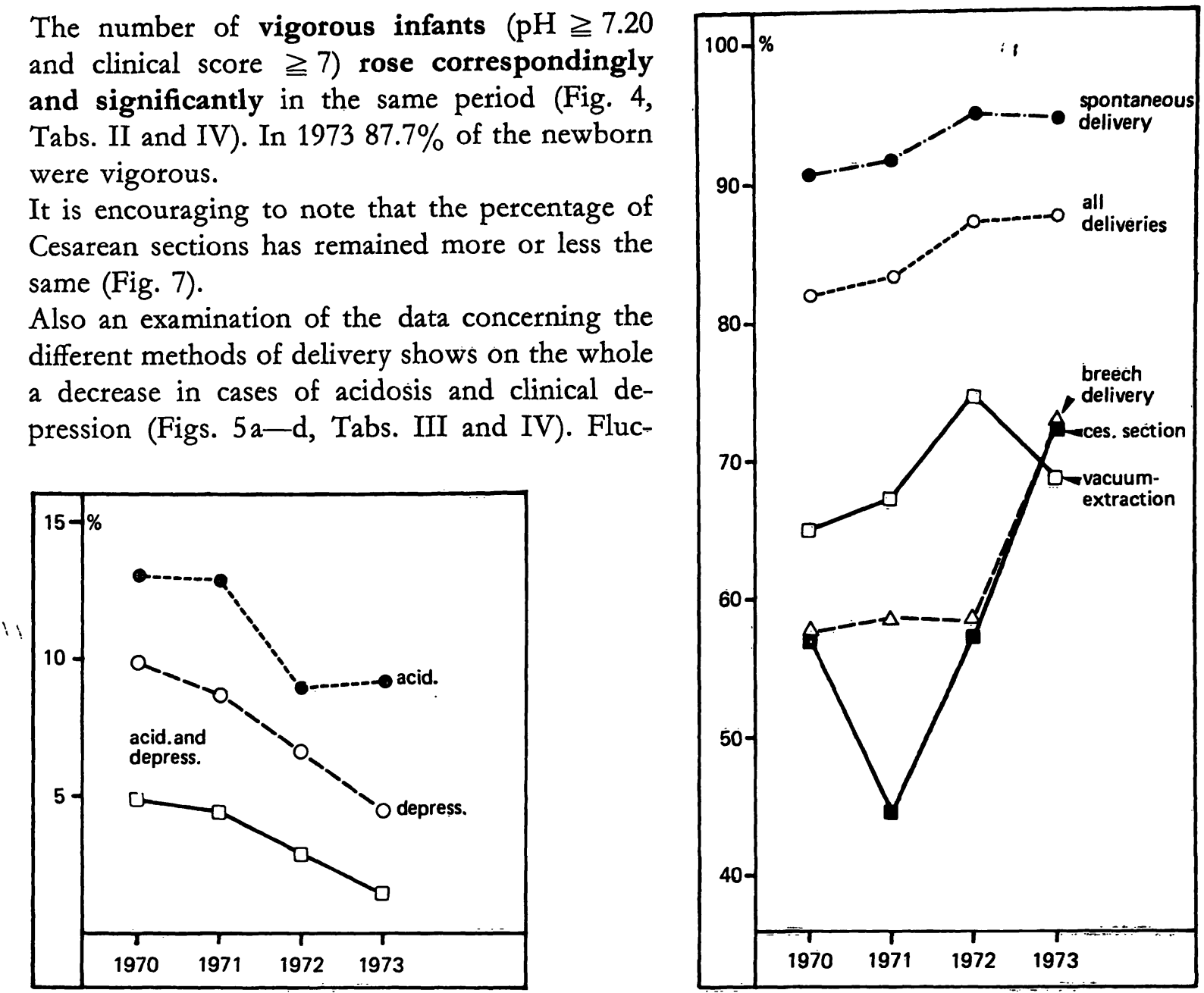

Fig. 3. Frequency of acidotic and depressed newborn in all cases scored.

Fig. 4. Frequency of vigorous newborn depending upon particular type of delivery.

Tab. II. Status of the newborn from 1970 until 1973.

\begin{tabular}{|c|c|c|c|c|c|c|c|c|}
\hline & \multicolumn{2}{|c|}{1970} & \multicolumn{2}{|c|}{1971} & \multicolumn{2}{|c|}{1972} & \multicolumn{2}{|c|}{1973} \\
\hline & No. & $\%$ & No. & $\%$ & No. & $\%$ & No. & $\%$ \\
\hline living newborns & 1243 & & 2368 & & 1802 & & 1667 & \\
\hline scored babies & 1042 & 83.8 & 2318 & 97.9 & 1760 & 97.8 & 1646 & 98.7 \\
\hline vigorous $A>I I I / C>I I I$ & 854 & 82.0 & 1921 & 82.9 & 1538 & 87.4 & 1444 & 87.7 \\
\hline acidotic $\mathrm{A} \leqq I I I$ & 136 & 13.1 & 298 & 12.9 & 157 & 8.9 & 152 & 9.2 \\
\hline depressed $C \leqq I I I$ & 103 & 9.9 & 202 & 8.7 & 116 & 6.6 & .74 & 4.5 \\
\hline 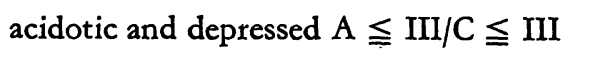 & 51 & 4.9 & 103 & 4.4 & 51 & 2.9 & 24 & 1.5 \\
\hline advanced or severe acidosis $\mathrm{A} \leqq \mathrm{II}$ & 46 & 4.4 & 73 & 3.2 & 35 & 2.0 & 21 & 1.3 \\
\hline moderately or severely depressed $\mathrm{C} \leqq \mathrm{II}$ & 37 & 3.6 & 62 & 2.7 & 54 & 3.1 & 24 & 1.5 \\
\hline both $\mathrm{A} \leqq \mathrm{II} / \mathrm{C} \leqq \mathrm{II}$ & 15 & 1.4 & 23 & 1.0 & 11 & 0.6 & 5 & 0.3 \\
\hline
\end{tabular}




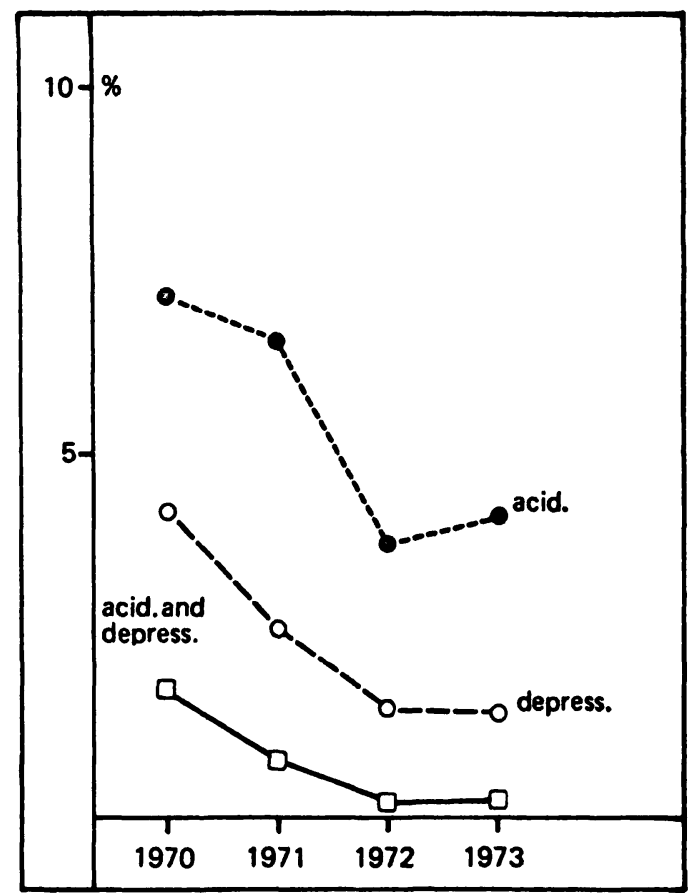

Fig. 5a. Frequency of acidotic and depressed newborn after spontaneous delivery.

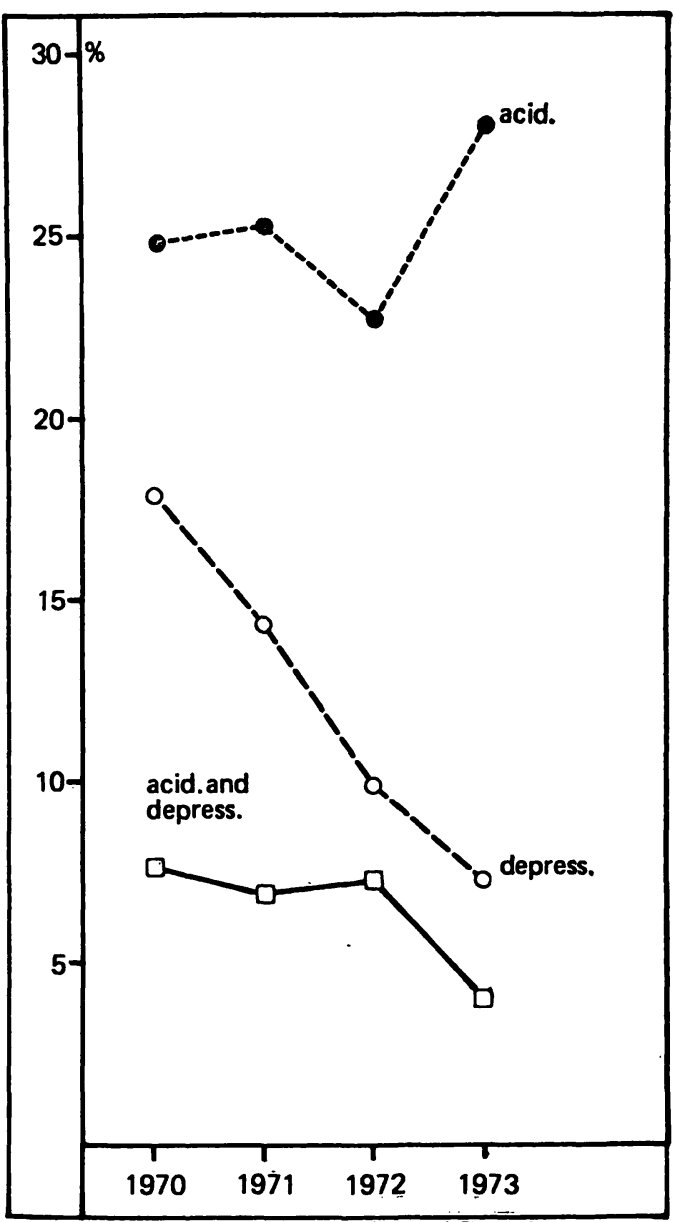

Fig. 5b. Frequency of acidotic and depressed newborn delivered by vacuumextraction.

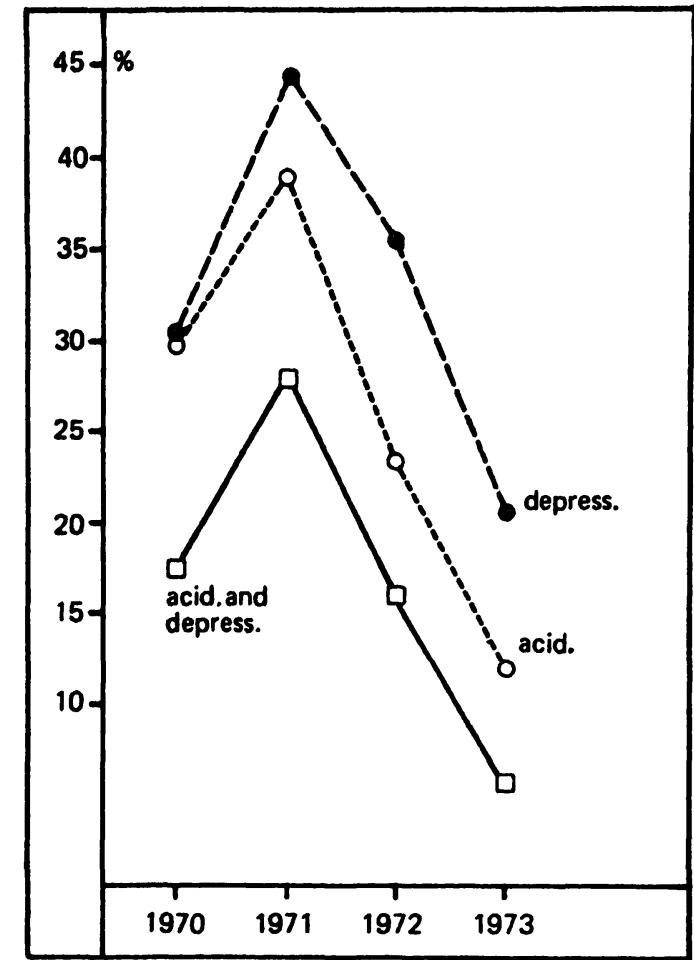

Fig. 5c. Frequency of acidotic and depressed newborn delivered by Cesarean section.

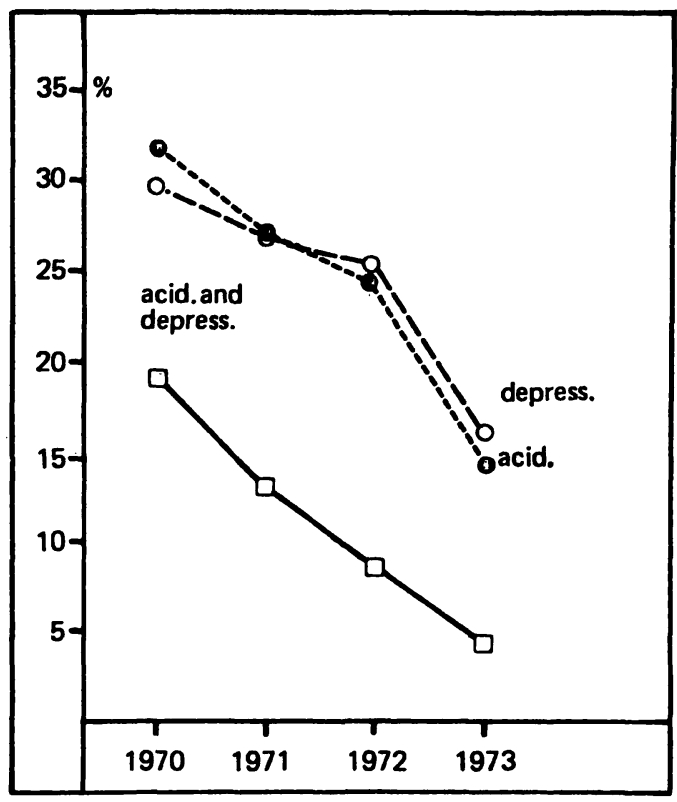

Fig. 5 d. Frequency of acidotic and depressed newborn in breech delivery. 
Tab. III. Status of the newborn and type of delivery.

\begin{tabular}{|c|c|c|c|c|c|c|c|c|}
\hline & \multicolumn{2}{|c|}{1970} & \multicolumn{2}{|c|}{1971} & \multicolumn{2}{|c|}{1972} & \multicolumn{2}{|c|}{1973} \\
\hline & No. & $\%$ & No. & $\%$ & No. & $\%$ & No. & $\%$ \\
\hline Spontaneous deliveries & 740 & 71.0 & 1700 & 73.3 & 1296 & 73.6 & 1179 & 71.6 \\
\hline $\begin{array}{l}\text { vigorous } A>I I I / C>I I I ~ \\
\text { acidotic } A \leqq I I I \\
\text { depressed } C \leqq I I I \\
\text { acidotic and depressed }\end{array}$ & $\begin{array}{r}669 \\
53 \\
31 \\
13\end{array}$ & $\begin{array}{r}90.4 \\
7.2 \\
4.2 \\
1.8\end{array}$ & $\begin{array}{r}1557 \\
113 \\
44 \\
14\end{array}$ & $\begin{array}{r}91.6 \\
6.6 \\
2.6 \\
0.8\end{array}$ & $\begin{array}{r}1231 \\
49 \\
19 \\
3\end{array}$ & $\begin{array}{r}95.0 \\
3.8 \\
1.5 \\
0.2\end{array}$ & $\begin{array}{r}1116 \\
49 \\
17 \\
3\end{array}$ & $\begin{array}{r}94.7 \\
4.2 \\
1.4 \\
0.3\end{array}$ \\
\hline Vacuum extraction & 157 & 15.1 & 348 & 15.0 & 232 & 13.2 & 278 & 16.9 \\
\hline $\begin{array}{l}\text { vigorous } \mathrm{A}>\mathrm{III} / \mathrm{C}>\mathrm{III} \\
\text { acidotic } \mathrm{A} \leqq \mathrm{III} \\
\text { depressed } \mathrm{C} \leqq \mathrm{III} \\
\text { acidotic and depressed }\end{array}$ & $\begin{array}{r}102 \\
39 \\
28 \\
12\end{array}$ & $\begin{array}{r}65.0 \\
24,8 \\
17.8 \\
7.6\end{array}$ & $\begin{array}{r}234 \\
88 \\
50 \\
24\end{array}$ & $\begin{array}{r}67.2 \\
25.3 \\
14.4 \\
6.9\end{array}$ & $\begin{array}{r}173 \\
53 \\
23 \\
17\end{array}$ & $\begin{array}{r}74.6 \\
22.8 \\
9.9 \\
7.3\end{array}$ & $\begin{array}{r}191 \\
78 \\
20 \\
11\end{array}$ & $\begin{array}{r}68.7 \\
28.1 \\
7.2 \\
4.0\end{array}$ \\
\hline Cesarean sections & 98 & 9.4 & 200 & 8.6 & 150 & 8.5 & 141 & 8.6 \\
\hline $\begin{array}{l}\text { vigorous } A>I I I / C>I I I \\
\text { acidotic } A \leqq I I I \\
\text { depressed } C \leqq I I I \\
\text { acidotic and depressed }\end{array}$ & $\begin{array}{l}56 \\
29 \\
30 \\
17\end{array}$ & $\begin{array}{l}57.1 \\
29.6 \\
30.6 \\
17.4\end{array}$ & $\begin{array}{l}89 \\
78 \\
89 \\
56\end{array}$ & $\begin{array}{l}44.5 \\
39.0 \\
44.5 \\
28.0\end{array}$ & $\begin{array}{l}86 \\
35 \\
53 \\
24\end{array}$ & $\begin{array}{l}57.3 \\
23.3 \\
35.3 \\
16.0\end{array}$ & $\begin{array}{r}102 \\
18 \\
29 \\
8\end{array}$ & $\begin{array}{r}72.3 \\
12.8 \\
20.6 \\
5.7\end{array}$ \\
\hline Breech deliveries & 47 & 4.5 & 70 & 3.0 & 82 & 4.7 & 48 & 2.9 \\
\hline $\begin{array}{l}\text { vigorous } \mathrm{A}>\mathrm{III} / \mathrm{C}>\mathrm{III} \\
\text { acidotic } \mathrm{A} \leqq \mathrm{III} \\
\text { depressed } \mathrm{C} \leqq \mathrm{III} \\
\text { acidotic and depressed }\end{array}$ & $\begin{array}{r}27 \\
15 \\
14 \\
9\end{array}$ & $\begin{array}{l}57.5 \\
31.9 \\
29.8 \\
19.1\end{array}$ & $\begin{array}{r}41 \\
19 \\
19 \\
9\end{array}$ & $\begin{array}{l}58.6 \\
27.1 \\
27.1 \\
12.9\end{array}$ & $\begin{array}{r}48 \\
20 \\
21 \\
7\end{array}$ & $\begin{array}{r}58.5 \\
24.4 \\
25.6 \\
8.5\end{array}$ & $\begin{array}{r}35 \\
7 \\
8 \\
2\end{array}$ & $\begin{array}{r}72.9 \\
14.6 \\
16.7 \\
4.2\end{array}$ \\
\hline
\end{tabular}

tuations occurring in some groups of operatively delivered infants are probably caused by the small number of cases. The few forceps deliveries are included in the group "vacuum extraction"; we did not deem it necessary to record these few cases (less than 10 per year) in an individual group.

Of course an infant born with slight acidosis and/ or clinical depression is not always in considerable danger. Therefore we set the limits higher and included all children born with advanced or severe acidosis $(\mathrm{pH}<7.10)$ and moderate or severe clinical depression (score $<5$ ). Even in this especially selected group we noticed a pronounced and highly significant decrease in the above cases (Fig. 6, Tabs. II and IV). In $19731.3 \%$ of all newborn had advanced or severe acidosis, $1.5 \%$ moderate or severe clinical depression and $0.3 \%$ both in combination.

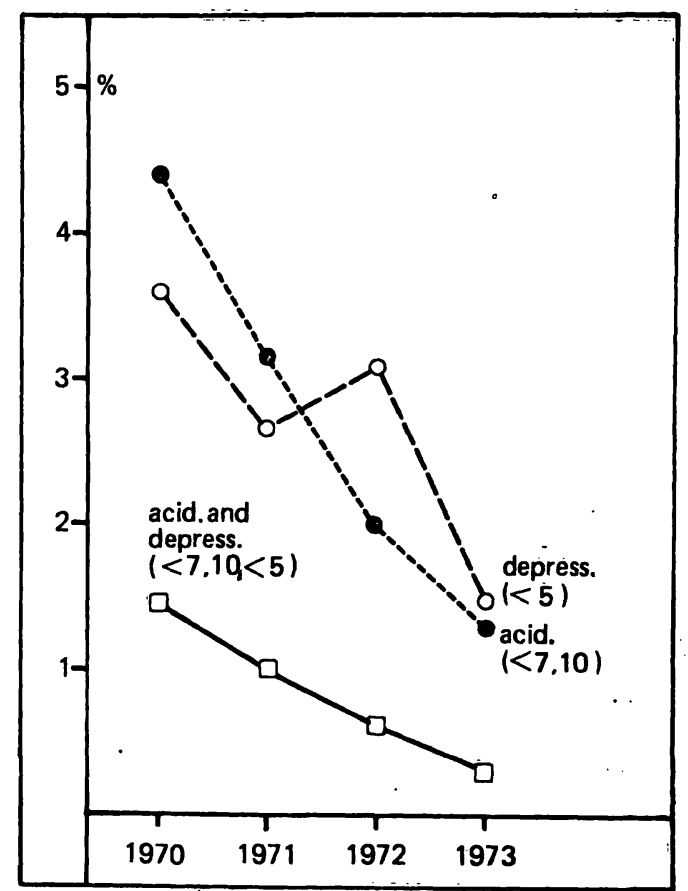

Fig. 6. Frequency of newborn with advanced or severe acidosis and moderate or severe clinical depression. 
Tab. IV. Diffcrence between 1970 and 1973. Calculation of significance*.

1) All newborns (s. Fig. 3, 4, 6)

\begin{tabular}{ll}
\hline $\begin{array}{l}\text { acidosis } \\
\text { depression }\end{array}$ & $\mathrm{p}<0.005$ \\
$\begin{array}{l}\text { acidosis and depression } \\
\quad \text { combined }\end{array}$ & $\mathrm{p}<0.001$ \\
vigorous newborn & $\mathrm{p}<0.001$ \\
\hline $\begin{array}{l}\text { advanced or severe acidosis } \\
\text { moderate or severe depression }\end{array}$ & $\mathrm{p}<0.001$ \\
$\begin{array}{l}\text { acidosis }(\mathrm{A}<\mathrm{II}) \text { and depression } \\
(\mathrm{C}<\mathrm{II}) \text { combined }\end{array}$ & $\mathrm{p}<0.001$ \\
\hline
\end{tabular}

2) Spontaneous deliveries (s. Fig. 4, 5a)

\begin{tabular}{ll}
\hline acidosis & $\mathrm{p}<0.005$ \\
depression & $\mathrm{p}<0.001$ \\
acidosis and depression & \\
$\quad$ combined & $\mathrm{p}<0.005$ \\
vigorous newborn & $\mathrm{p}<0.001$ \\
\hline
\end{tabular}

3) Vacuum extraction (s. Fig. 4, 5b)

\begin{tabular}{lll}
\hline $\begin{array}{l}\text { acidosis } \\
\text { depression }\end{array}$ & $\mathrm{p}>0.05$ & (n. s.*) \\
$\begin{array}{l}\text { acidosis and depression } \\
\quad \text { combined }\end{array}$ & $\mathrm{p}<0.005$ & \\
vigorous newborn & $\mathrm{p}>0.05$ & $\left(\right.$ n. s. $\left.{ }^{*}\right)$ \\
\hline
\end{tabular}

4) Cesarean section (s. Fig. 4, 5c)

\begin{tabular}{ll}
\hline $\begin{array}{l}\text { acidosis } \\
\text { depression }\end{array}$ & $\mathrm{p}<0.005$ \\
$\begin{array}{l}\text { acidosis and depression } \\
\quad \text { combined }\end{array}$ & $\mathrm{p}>0.05 \quad$ (n. s.*) \\
\begin{tabular}{l} 
vigorous newborn \\
\hline
\end{tabular} & $\mathrm{p}<0.01$ \\
\hline
\end{tabular}

5) Breech deliveries (s. Fig. 4, 5d)

\begin{tabular}{lll}
\hline $\begin{array}{l}\text { acidosis } \\
\text { depression }\end{array}$ & $\mathrm{p}>0.05$ & (n. s.*) \\
$\begin{array}{l}\text { acidosis and depression } \\
\quad \text { combined }\end{array}$ & $\mathrm{p}>0.05$ & (n. s.*) \\
vigorous newborn & $\mathrm{p}<0.05$ & \\
\hline
\end{tabular}

* There is a significant difference when " $\mathrm{p}$ " is less than 0.05 . The non-significant differences are marked.

\section{Summary}

Since July 1, 1970 for every infant born in our clinic we have recorded a combined clinical-biochemical score. In the present article these data were examined. The question for us was, whether the condition of the newborn immediately after birth has improved in the last years.

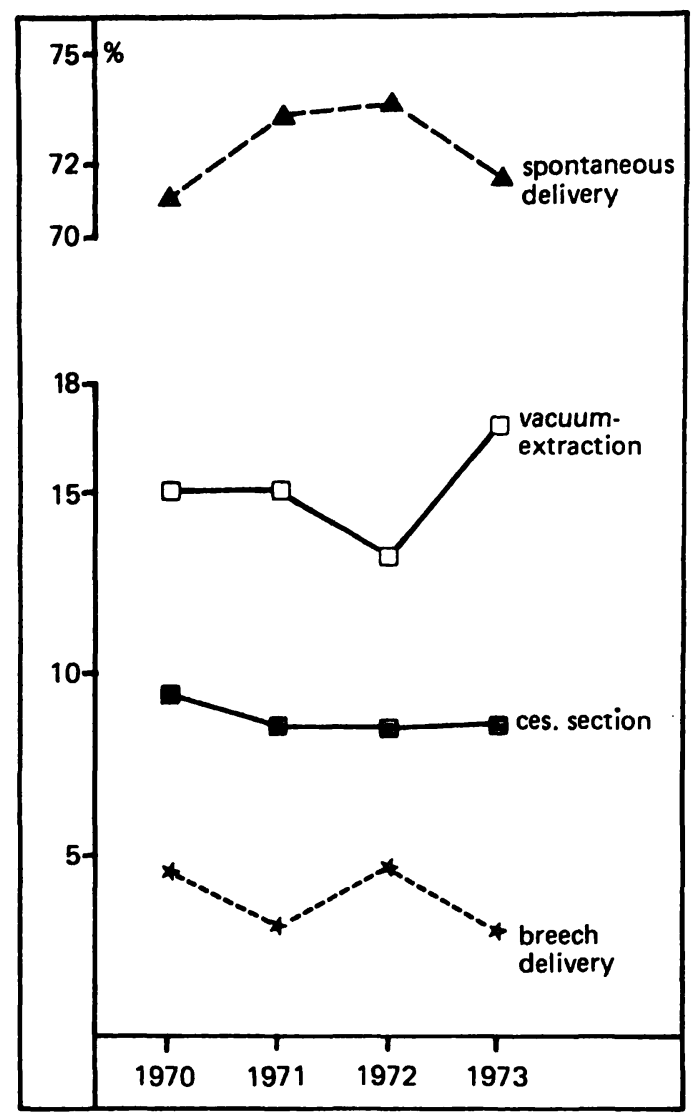

Fig. 7. Distribution of the different types of delivery.

This group of cases must be considered to be particularly endangered. The number of these infants must definitely be further reduced.

\section{Conclusions}

In progressive obstetrics the reduction of morbidity must today be emphazised more and more. We have to decrease the number of infants with cerebral damage, resulting from hypoxic injury in late pregnancy and during delivery. Because of its dependability for assessing neonatal condition and the objectivity of the $\mathrm{pH}$-value from the umbilical artery blood, this parameter should be included in every evaluation of the newborn infant. Thus we were able to make better comparisons of the results from different departments.

The clinical and the acidity score were divided into groups [4], as can be seen in Fig. 2.

We have shown, that the number of infants with acidosis $(\mathrm{pH}<7.20)$ and clinical depression (score $<7$ ) has decreased with statistical significance (Fig. 3, Tabs. 
II and IV). Cases of acidosis occurred in the last year in only $9.2 \%$, clinical depression in $4.5 \% ; 1.5 \%$ of the newborn suffered from acidosis as well as clinical depression. During the same period the number of vigorous newborn ( $\mathrm{pH} \geqq 7.20$ and clinical score $\geqq 7$ ) increased significantly (Fig. 4, Tabs. II and IV). In $197387.7 \%$ of the newborn were vigorous.

The number of infants with advanced or severe acidosis $(\mathrm{pH}<7.10)$ and/or moderate or severe clinical depression (score $<5$ ) decreased significantly. In 1973 1.3\% of all neonates had advanced or severe acidosis, $1.5 \%$ moderate or severe clinical depr'ession and $0.3 \%$ both in combination (Fig. 6, Tabs. II and IV). Also in respect to the different types of delivery a similar trend is shown (Figs. 5a-d, Tabs. III and IV).

The frequency of Cesarean sections has remained approximately the same during this period (Fig. 7).

Because of its dependability for assessing neonatal condition and its objectivity, the acidity score should be included in every evaluation of the newborn infant.

Keywords: Acidosis, ApGar-score, cardiotocography, depression, fetal blood analysis, monitoring (fetal), morbidity, newborn, score (biochemical), score (clinical).

\section{Zusammenfassung}

Kombiniertes klinisch-chemisches Zustandsschema des Neugeborenen. Ergebnisse 1970 bis 1973.

Seit dem 1. 7.1970 erfolgte an unserer Klinik in der Regel bei jedem Neugeborenen eine kombinierte klinisch-biochemische Zustandsdiagnostik. In der vorliegenden Arbeit wurde das gesamte bis jetzt vorhandene Material einer Untersuchung unterzogen; für uns stellte sich die Frage, ob im Laufe der letzten Jahre im Zustand der Neugeborenen unmittelbar post partum eine Besserung eingetreten ist. Der klinische und der Aziditäts-Status wurden in Gruppen eingeteilt [4], (Fig. 2). Wir konnten zeigen, daß die Anzahl der azidotischen und der klinisch deprimierten Neugeborenen in den letzten Jahren statistisch signifikant abgenommen hat (Fig. 3, Tab. II und IV). Azidosen ( $\mathrm{pH}<7,20$ ) kamen zuletzt nur noch in 9,2\%, klinische Depressionen (Punkte $<7$ ) in $4,5 \%$ der Fälle vor. $1,5 \%$ der Neugeborenen waren sowohl azidotisch als auch klinisch deprimiert.

Schlüsselwörter: Azidose, Apgar Punkteschema, Depression, Fetalblutanalyse, Kardiotokographie, Morbidität, Neugeborenes, Punkteschema (biochemisch, klinisch), Überwachung (intrapartuale).

\section{Résumé}

Schème clinico-chimique combiné sur l'état des nouveaux-nés. Résultat 1970-1973.

Depuis le 1.7.1970 il était devenu de règle dans notre clinique de procéder à un diagnostic clinico-chimique combiné sur l'état de chaque nouveau-né. Le présent article porte sur l'analyse de toutes les observations effectuées jusque là, avec pour object principal de savoir si l'état des nouveaux-nés aussitôt post partum s'était amélioré au cours des ans. Les status clinique et d'acidité ont été classés et ordonnés [4], (Fig. 2), ce qui a permis d'observer que le nombre des nouveaux-nés acidosiques et des nouveaux-nés en mauvais état clinique a diminué de façon statistiquement significative au cours des dernières années (Fig. 3, Tab. II et IV). Les acidoses $(\mathrm{pH}<7,20)$ n'apparurent plus que dans $9,2 \%$ des cas, et les dépressions cliniques (points < $<$ ) dans $4,5 \%$ des cas. $1,5 \%$ des nouveaux-nés étaient aussi bien acidosiques que dans un mauvais état clinique.

Durant la même période, on observa une hausse significative du nombre des enfants nés en parfait état de
Im gleichen Zeitraum stieg die Anzahl der lebensfrisch geborenen Kinder ( $\mathrm{pH} \geqq 7,20$ und $\geqq 7$ Punkte) signifikant an (Fig. 4, Tab. II und IV). 1973 waren 87,7\% der Neugeborenen lebensfrisch. Die Fälle, in denen Kinder mit fortgeschrittener oder schwerer Azidose ( $\mathrm{pH}<7,10)$ bzw. mittelschwerer und schwerer klinischer Depression (Punkte $<5)$ geboren wurden, nahm signifikant ab. 1973 hatten 1,3\% aller Neugeborenen eine fortgeschrittene oder schwere Azidose, 1,5\% einen mittelschweren oder schweren Depressionszustand und $0,3 \%$ beides in Kombination (Fig. 6, Tab. II und IV).

Auch bei Aufschlüsselung in die verschiedenen Geburtsarten ist ein ähnlicher Trend erkennbar (Fig. 5a-d, Tab. III und IV).

Die Häufigkeit der Schnittentbindung ist während dieser Jahre etwa gleich geblieben (Fig. 7).

Wegen seiner großen Aussagekraft und der Objektivität sollte die Beurteilung des Aziditäts-Status bei keiner Zustandsdiagnostik des Neugeborenen fehlen. santẻ ( $\mathrm{pH} \geqq 7,20$ et $\geqq 7$ points) (Fig. 4, Tab. II et IV). En 1973, 87,7\% des nouveaux-nés étaient sains. Les cas de naissance d'enfants avec acidose avancée ou grave $(\mathrm{pH}$ $<7,10$ ) ou, respectivement, dépression clinique de degré moyen à grave (points $<5$ ) diminuèrent de façon significative. En 1973, 1,3\% de tous les nouveaux-nés avaient une acidose avancée ou grave, $1,5 \%$ un état dépressif moyen ou grave et $0,3 \%$ les deux combinés (Fig. 6, Tab. II et IV).

Même une classification selon les diverses formes de naissance révèle une tendance similaire (Fig. 5a-d, Tab. III et IV).

La fréquence des césariennes est restée à peu près la même durant ces années (Fig. 7).

En raison de son importante signification et par souci d'objectivité, l'appréciation du status d'acidité ne devrait jamais être omise dans les diagnostics relatifs à l'ẹtat des nouveaux-nés.

Mots-clés: Acidose, schème de points APGAR, dépression, analyse du sang foetal, cardiotocographie, morbidité, schème par points pour le nouveau-né (biochimique, clinique), surveillance (intrapartuale). 


\section{Bibliography}

[1] APGAR, V.: A proposal for a new method of evaluation of the newborn infant. Curr. Res. Anesth. 32 (1953) 260

[2] Saling, E.: Neue Untersuchungsmöglichkeiten des Kindes unter der Geburt (Einführung und Grundlagen). Geburtsh. u. Frauenheilk. 21 (1961) 905
[3] Saling, E.: Zustandsdiagnose beim Neugeborenen unmittelbar nach der Gcburt. Gynaecologia 160 (1965) 133

[4] Saling, E., K. H. Wulf: Zustandsdiagnose beim Neugeborenen. Gruppeneinteilung. Fortschr. Med. 89 (1971) 12

Prof. Dr. E. Saling

Dr. H. Boenisch

Unit of Perinatal Medicine

Mariendorfer Weg 28-38

D-1000 Berlin 44/Germany 